Indian Traffic 



\section{Indian Traffic}

Identities in Question in Colonial and Postcolonial India

\section{Parama Roy}

UNIVERSITY OF CALIFORNIA PRESS

Berkeley Los Angeles London 


\author{
University of California Press \\ Berkeley and Los Angeles, California \\ University of California Press, Ltd. \\ London, England \\ (C) 1998 by \\ The Regents of the University of California
}

Versions of chapters 1 and 2 appeared in boundary 2 ("Oriental Exhibits: Englishmen and Natives in Burton's Personal Narrative of a Pilgrimage to Al-Madinah and Meccah," boundary 2 22, no. 1 [1995]: 185-210) and the Yale Joumal of Criticism ("Discovering India, Imagining Thuggee," Yale Journal of Criticism 9, no. 1 [1996]: 121-45), respectively. I thank both journals for their permission to reprint this material. A shorter version of chapter 4 appeared as "As the Master Saw Her," in Cruising the Performative: Interventions into the Representation of Ethnicity, Nationality, and Sexuality, edited by Sue-Ellen Case, Philip Brett, and Susan Leigh Foster, 11 2-29 (Bloomington: Indiana University Press, 1995).

Photographs reprinted courtesy of the Vedanta Society of Northern California.

Library of Congress Cataloging-in-Publication Data

Roy, Parama.

Indian traffic: identities in question in colonial and postcolonial India / Parama Roy. p. $\mathrm{cm}$.

Includes bibliographical references and index.

ISBN 0-520-20486-7 (alk. paper). -ISBN 0-520-20487-5 (alk. paper)

1. Indic literature (English)-History and criticism. 2. National characteristics, East Indian, in literature. 3. Literature and society-India-History-2oth century. 4. Anglo-Indian literature-History and criticism. 5. Group identity in literature. 6. Decolonization in literature. 7. Nationalism-India-History. 8. Imperialism in literature. 9. British-India-History. 10. Colonies in literature. 11. Group identity-India. 12. India-Civilization. I. Title.

PR9485.2.R69 1998

$820.9^{\prime} 954$-dc2o

$96-42104$

Printed in the United States of America

$\begin{array}{lllllllll}9 & 8 & 7 & 6 & 5 & 4 & 3 & 2 & 1\end{array}$

The paper used in this publication meets the minimum requirements of American National Standards for Information Sciences-Permanence of Paper for Printed Library Materials, ANSI 239.48-1984. 